\title{
臥位での指示代名詞による領域分節に関する実験的研究 THE EXPERIMENTAL STUDY ON REFERENCE DOMAINS OF DEMONSTRATIVE PRONOUNS FROM RECLINING POSTURES
}

\author{
橋 本 雅好*, 西出和 彦**, 高 橋 鷹 志*** \\ Masayoshi HASHIMOTO, Kazuhiko NISHIDE and Takashi TAKAHASHI
}

\begin{abstract}
The purpose of this study is to clarify the reference domains of demonstrative pronouns from reclining postures. In everyday conversation in Japan, we use the three different demonstrative pronouns, "KORE", "SORE", and "ARE". The differences between the usage of these three pronouns indicate that the space surrounding a person can be divided into three reference domains. The experiments were carried out in a large experimental room. Subjects were located lying on one's back on the bed. Subjects were indicated the electric bulb, then were asked to KORE/SORE/ARE. The results are summarized as below;

1) The reference domain of "ARE" encloses the domain of "SORE", which encloses the domain of "KORE".

2) The reference domain of "KORE" encloses from head to knee, and has relation to the motion area of the arm.

3) The reference domains of demonstrative pronouns from reclining postures are different from the reference domains of demonstrative pronouns from standing postures.
\end{abstract}

Keywords: reclining postures, demonstrative pronouns, motion area, derection of eyes 臥位、指示代名詞、動作域、視線の方向

1. 序

\section{1 研究の背景と目的}

人の身体を取りまく空間には、言葉の使い分けによって目には見え ない心理的領域が形成されているといわれている。特に、事物を指し 示す指示代名詞注1)「これ・それ・あれ」の使い分けによって領域が分 節されていることについては、言語学や人文科学といった分野で、実 験的に検証されている文2-4)。

例えば、今井四郎 (1978) 文2 は、人形を用いた実験で、玩具の缶 を指示させ、「○○は缶です」の○○に、「れ・それ・あれ」のいづ れかを入れて回答させる実験をおこない、石川守 (1992) 文3) は、屋 内や屋外で、様々なブロックを指示させる同様の実験をおこない、指 示代名詞の使い分けによってできる心理的領域 (以後、指示代名詞領 域とする）の平面的な領域構成を明らかにした（図 1)。

また、橋本都子ら（1996）文4）も同種の手法を用いて、立位での指 示代名詞領域について㭘証し、指示代名詞領域（「コレ」領域）の 3 次元的形状を定量的に明らかにした（図 2)。

これらの実験では、被験者の姿勢が立位でおこなわれており、臥位 の場合についてはおこなわれていない泣21。この理由として、立位は人 間の生活姿勢の基本形であることや、臥位については、「臥位＝睡眠 姿勢」と捉えられ、寝心地や睡眠状況などが、卧位の研究の視点とな
りやすかったことなどが挙げられる。

しかしながら、我々の生活の中で、眠る以外にも卧位で休息をとっ たり、読書をしたりする行為は、日常的におこなわれている。特に、 病室での患者の生活は、ベッド上で臥位の状態でいることが多い。

そこで本研究では、姿勢が臥位の場合における身体を取りまく心理 的領域の形状について、指示代名詞の使い分けの分析によって検証す ることを目的とした実験を実施した。

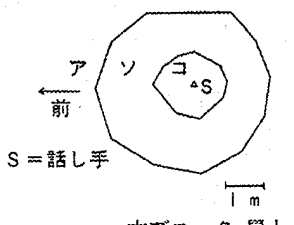

*ブロック篦上

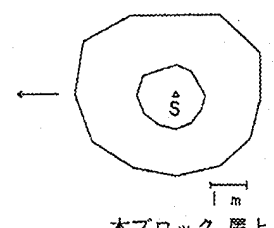

ホブロック㗨上
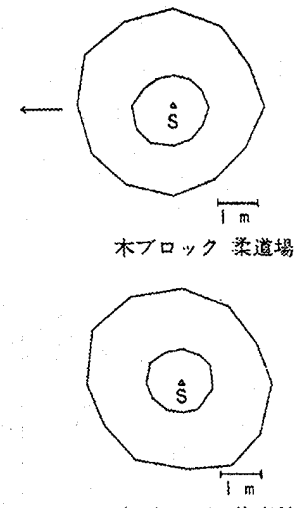

ホブロック体前的官
図 1. 立位での指示代名詞領域の平面的形状文3)

\footnotetext{
本研究は, 参考文献17)に追加分析・修正・考察等を加之, 発展させたものである。

* 平安女学院大学生活環境学部生活環境学科加え, 無展させたものである。 Lecturer, Dept. of Human Life and Environment, Faculty of Human Life and 講師・博士 (工学)

** 東京大学大学院工学系研究科建築学専攻. 助教授・博士 (工学)

*** 元 新潟大学大学院自然科学研究科 教授. 工博 Environment, Heian Jogakuin (St. Agnes') University, Dr. Eng.

Assoc. Prof., Dept. of Archit., Graduate School of Eng., The Univ. of Tokyo, Dr. Eng.

(One-time), Prof., Graduate School of Science and Technology, Univ. of Niigata, Dr. Eng.
} 


\section{2 既往の関連研究}

人の身体のまわりには、目には見えないがある程度の大きさを持っ た一種のなわばりが形成されていると考えられている。こことが論 じられた先駆的研究としては、Sommer, R. (1972) 文6) のPersonal Space (パーソナルスペース、個人的空間) 注3) に関する研究と Hall, E.T. (1970) 奴 の Proxemics（プロクセミクス、近接学）に関する研究が 挙げられる。Sommer, R.は、様々な状況における人と人との距離（空 間）のとり方の観察から、人がもつ Personal Spaceの概念について検 証した。また、Hall, E.T.も同様に、人の行動を観察することによって、 人と人がとる距離間隔を、コミュニケーションをとるためのツールと 考え、その距離とコミュニケーションを関連づけて、4つの距離帯 （密接距離、個体距離、社会距離、公衆距離）を示した。

その後も、人の身体を取りまく心理的領域に関心を抱いた研究は、 教育・社会・環境心理学の分野を中心におこなわれている文8-10)。

例えば、田中政子 (1973) 文8) は、相手を 8 方向から接近させ、「近 すぎて気詰りな感じがする」地点を計測する実験をおこない、Personal Spaceの形状の異方性を明らかにした。渋谷昌三 (1990) 文9) も「それ 以上近づいてほしくない」地点を計測し、Personal Spaceの形状は、年 齢、性別、対人関係によって異なることを明らかにした。西出和彦 (1991）文10) は、人間が集合したときに現れる空間的位置関係を、実験 や行動観察など様々な手法を用いて検証し、対人距離とコミュニケー ションとの関係によって、Hall, E.T.の距離帯と照らし合わせ、5つの 距離帯（排他域、会話域、空間共有域、相互認識域、識別域）を提唱 した。

指示代名詞「これ・それ・あれ」以外の言炗の使い分けによる領域 分節に着目した研究としては、大野隆造ら（1999）文11) の人と空間構 成要素（壁、柱）との位置関係を「そば・あいだ・なか・そと」といっ た日常的に用いる言葉によって検証した研究がある。この研究では、 「そば・あいだ・なか」といった言葉によって、物理的要素まわりの 空間の広がりを明確に規定できることを明らかにし、相手がいる場合 における相手の占有領域の広がりと「そば・あいだ・なか」の使い分 けとの関連性を示した。

以上のような Personal Space や対人距離といった概念は、必ず相手 がいることによって現れる心理的領域といえるが、指示代名詞領域 は、指示代名詞の性質上、相手がいる場合（相手に伝える状況）と相 手がいない場合 (自分自身に問う状況) との 2 種類の領域が現れる点 で Personal Spaceの概念とは異なるといえる。本研究では、相手がい ない場合での指示代名詞領域を対象としている。

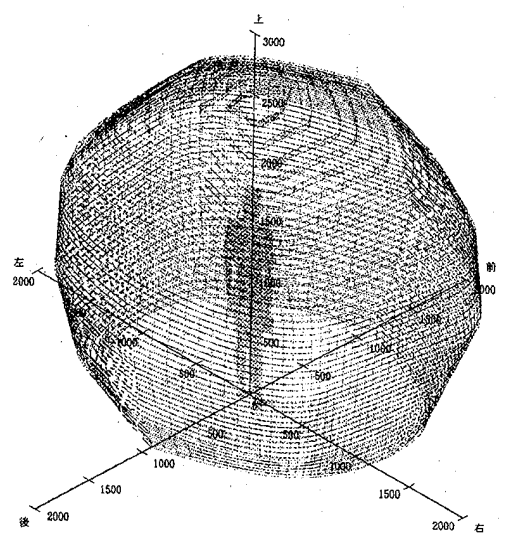

図2. 立位での「コレ」の領域の 3 次元的形状文31

\section{2. 実験の概要}

\section{1 実験場・実験装置と被験者の属性}

実験場は、天井や壁といった物理的要素による影響を受けないと考 えられる空間的広さがある体育館内とした注4。その館内の中心に被験 者が横たわるベッド（長さ：1900、幅：700、高さ：640、[単位：mm、 以後省略]）を設置した。被験者が指示する物（指示物）は、角パイ プに 450 ピッチでとり付けた電球（直径：40、60W）とし、指示物ま での高さが基準点（被験者の両目の中心、床面からの高さ：845）か ら 300、600、900、1200、1500、1800、2100、2400、2700の 9 種類、 指示物までの水平距離が基準点から 0、450、900、1350、1800、2250 の 6 種類、指示物の方向が上、斜め上、横、斜め下、下の 5 種類が設 定できるように、指示物をとり付けた角パイプを支える槽を組んだ (写真 1、図 3)。設定した指示物のポイントは 234 ポイントである。 また、被験者は建築・デザイン系の大学生の男性 6 名（平均身長： 1732)、女性 6 名（平均身長：1588）の合計 12 名（平均身長：1660）と した注5)。

\section{2 実験の方法}

被験者は、最初に実験の教示注6)を受けた後、ベッド上に横になり、 明かりのついた電球を指さし、「○○は何だろう」・「○○は電球です 」と言うときに○○のところに指示代名詞「コレ・ソレ・アレ」のい ずれを用いるかを回答シートに記入する。この一連の過程を繰り返し おこなう。また、被験者への指示物の呈示はランダムにおこなった。

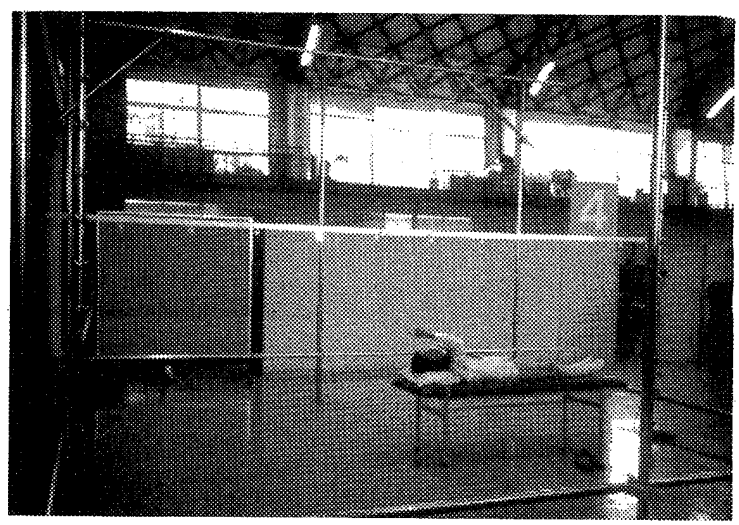

写真 1 . 実験装置と実験風景

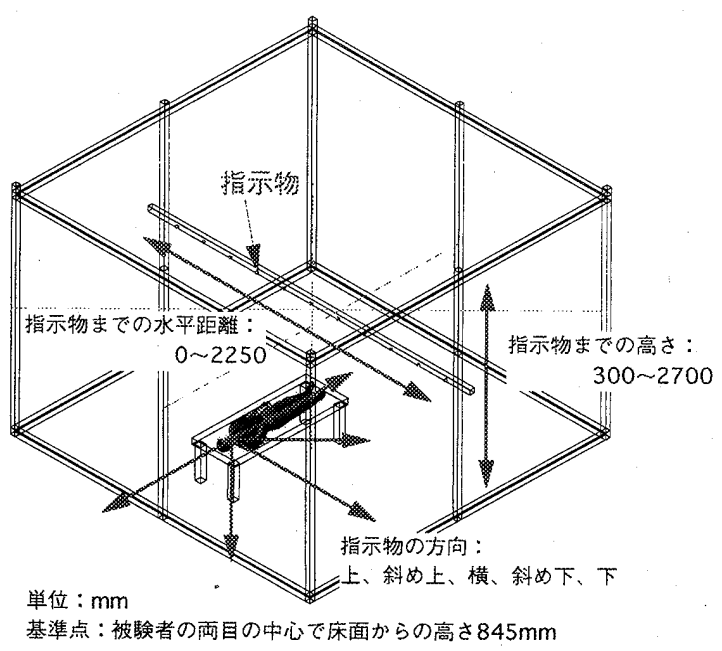

図 3. 実験場と実験装置 


\section{3. 実験の結果と分析}

\section{1 分析の方法}

各ポイントにおいて被験者の回答が「コレ・ソレ・アレ」のいずれ に多いかに対する $\chi^{2}$ 検定および多重比較をおこなった注》。有意水準 は $5 \%$ と $10 \%$ 以下とした。分析の実例の一部を図 4 に示す。それぞれ の有意水準で有意差がみられたポイントには「コレ」は，○、「ソレ」 はム、、、「アレ」はロ, 口で示し、有意差がみられなかったポイント にはメで示した。作図の段階では、有意差なし（×印）で示された「コ レ」と「ソレ」や「ソレ」と「アレ」に評価が分かれた部分を「グレー ゾーン」とした注8)。

\section{2 臥位での指示代名詞領域の分布様態}

すべてのポイントで検定をおこなった結果による臥位での指示代名 詞領域の分布様態を図 5 ～8に示す注99。臥位での指示代名詞領域は、 身体から遠のくにしたがい、「コレ」、「ソレ」、「アレ」の順に領域が 変化し、身体を球状にとり囲む広がりを示した。

「コレ」領域の形状は、指示物までの水平距離が、上方向：0４50 の間、下方向：900付近、横方向：450～900の間で、指示物までの高 さが900〜1200の間であった。垂直方向では、900～1200の間であっ た。これらのことから、「コレ」領域の形状は、身体の頭から膝あた

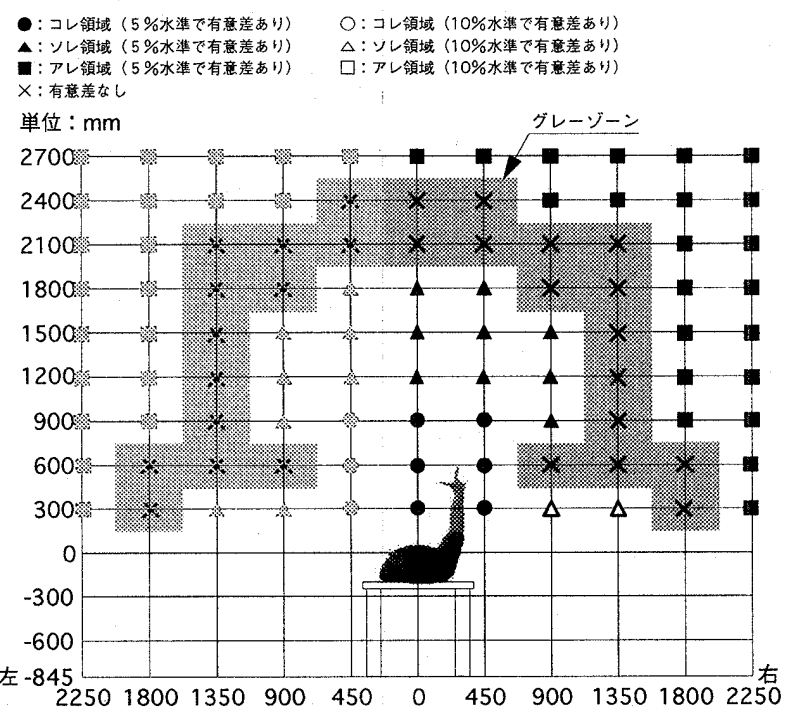

図 5. 臥位での指示代名詞領域の分布様態（左右方向）

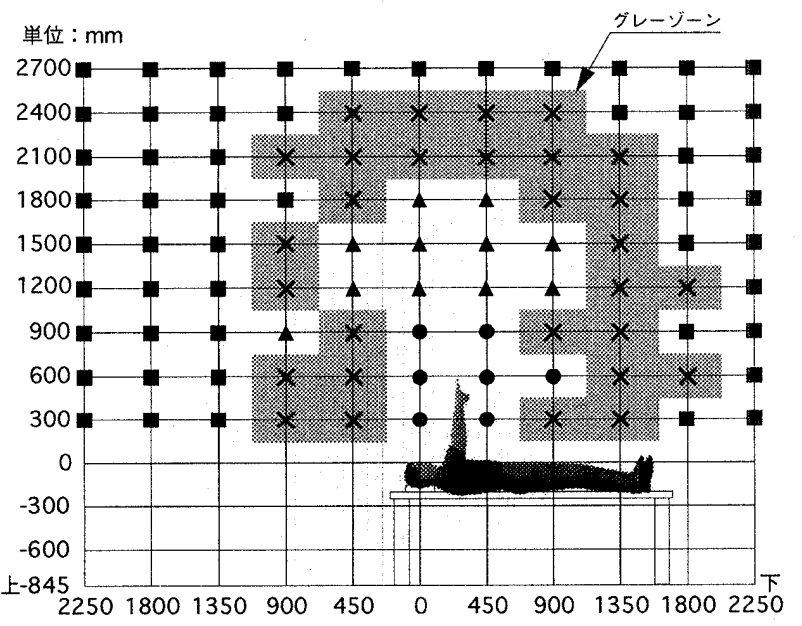

図 6. 臥位での指示代名詞領域の分布様態（上下方向）
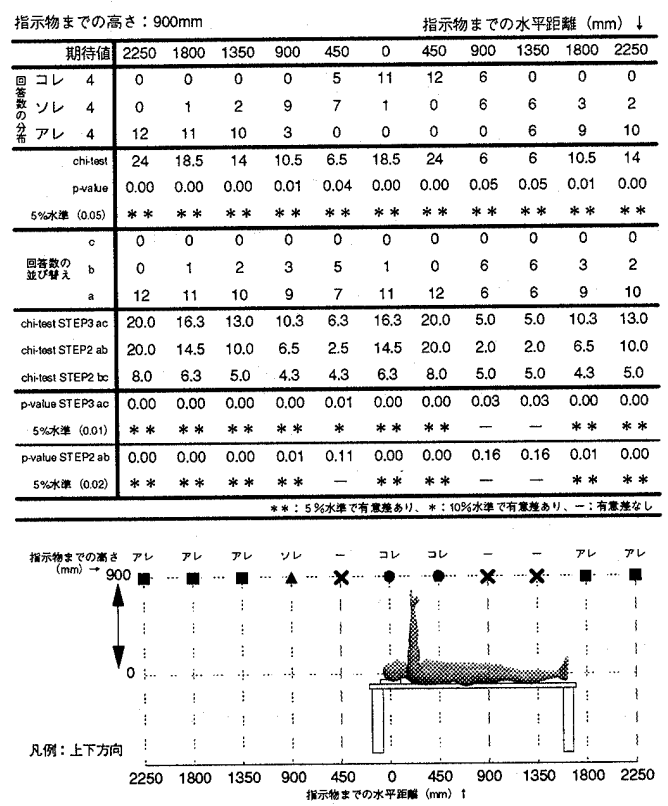

図 4. 分析の方法

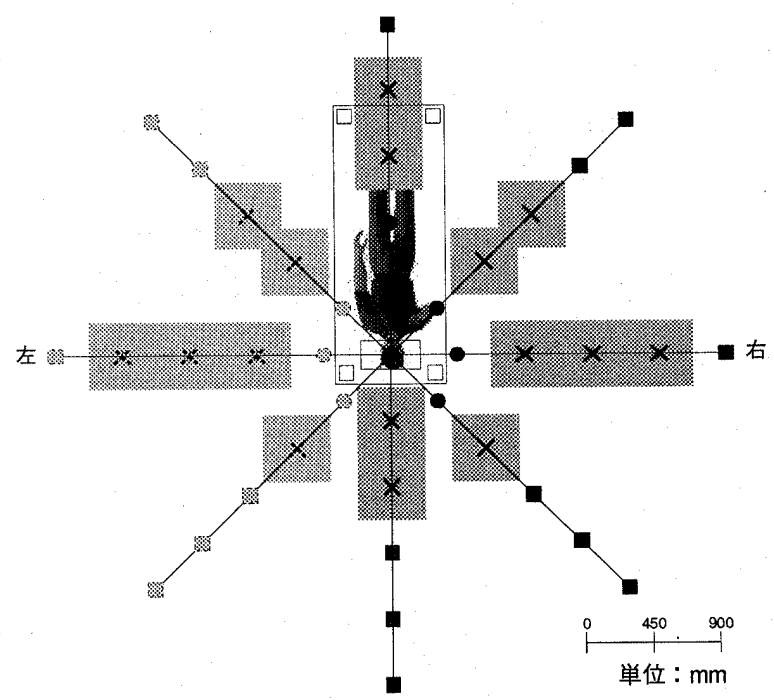

国 7. 臥位での指示代名詞領域の分布様態（指示物の高さ 600）

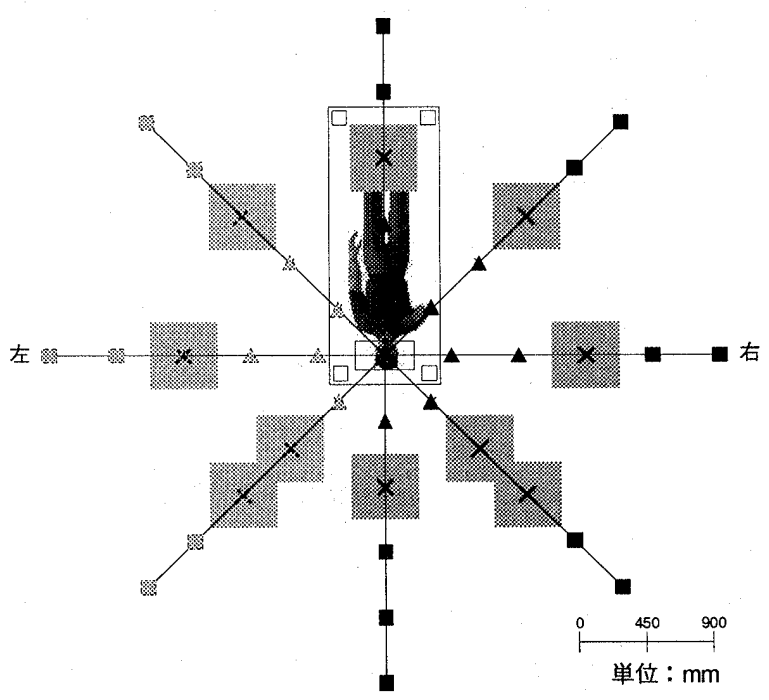

図 8. 臥位での指示代名詞領域の分布様態（指示物の高さ 1500） 
りまでを包み込み、視点から 1000 付近を頂点とした卵型をしている と考えられる。

また、「ソレ」と「アレ」の領域の境界については、「コレ」と「ソ レ」の領域の境界よりもグレーゾーンとなる部分が多く、領域の境界 が曖昧であった。その中で「ソレ」領域の形状の傾向をみると、指示 物までの水平距離は、上方向：900付近、横・下方向：1350付近で、指 示物までの高さは2100〜2400の間と推測できる。

全体的な指示代名詞領域の広がりは、「コレ」・「ソレ」領域ともに、 頭上方向への広がりが狭く、垂直方向 (視線の方向)への広がりが広 くなる傾向がみられた。これは、頭上方向には視線が送りにくく、垂 直方向は、視線が送りやすいためと考えられる。つまり、指示代名詞 領域は、見えやすさによって変化し、領域の広がり方が異なる傾向が あるといえる。

\section{4. 考察}

4.1 臥位での「コレ」領域の大きさが持つ意味

指示代名詞の分布様態の分析によって、「コレ」領域は「ソレ」領 域に比べ、領域の境界が明確に表れていたことから、「コレ」と「ソ レ」の領域の境界部分に境界線を引き「コレ」領域を示した（図 9 . 10）注10)。「コレ」領域は、身体の頭から膝あたりまでを包み込む卵型 であるといえる注11。

この「コレ」領域の大きさと臥位での動作域文14) とを比較すると(図 9 )、重なり合う部分が多く、「コレ」領域の水平方向の広がりは、手

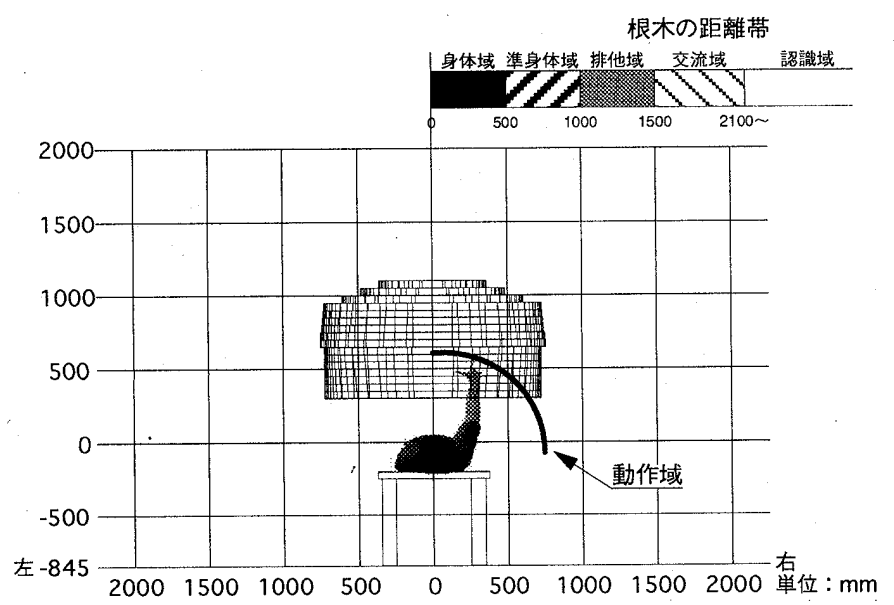

図 9. 臥位での「コレ」領域の大きさと動作域との関係 (左右方向)

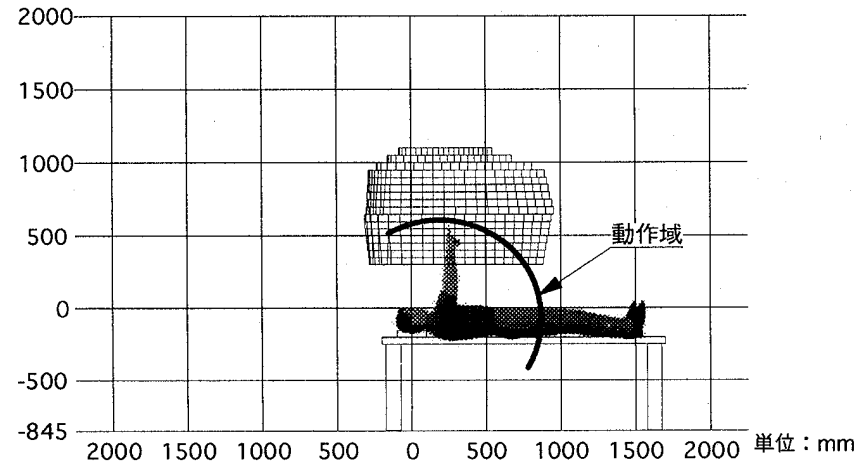

図 10. 臥位での「コレ」領域の大きさと動作域との関係 (上下方向)
が届きそうな範囲と考えることができる注12)。また、指示代名詞「こ れ」は「自分のなわばりのもの」を示す文15) ど言われていることから も、自分の手が届きそうな範囲を自分のなわばりと感じ、その大きさ は「コレ」領域で表すことができると考えられる。

また、「コレ」領域の水平方向の広がりと根木睦二 (1984) 文16) が示 した臥位の距離带注13) を比べると（図 9)、「コレ」領域は、準身体域 に相当する。この距離は、「手を伸ばすと相手に触れることができる が、親密な間柄でない限り不快に感じる」距離とされている。言い換 えれば、人にそれ以上近づかれたくないという距離と解釈できる。

これらのことから、臥位での「コレ」領域は、「自分のなわばりで あり、それよりも内側に人を侵入させたくない領域」であると考える ことができる。

\section{2 臥位での「コレ」領域と立位での「コレ」領域との比較}

ここでは、本研究での臥位での「コレ」領域の結果と橋本都子 （1996）文4〉の立位の「コレ」領域の結果を比較し、姿勢の違いが指示 代名詞領域に与える影響について検証し、臥位の特異性を検証した。 4.2 .1 立位での指示代名詞領域に関する実験の概要文4

ここでは、立位での実験の概要を記す。実験の目的は、空間的な制 約の少ない場所 (体育館)における立位姿勢での指示代名詞の使い分 けに着目して、指示代名詞領域の 3 次元的な形状を明らかにすること であうた。実験の概要を表 1 に示す。指示物（ビニールボール）まで の高さが床面から $0 \sim 6200$ の 15 種類、指示物までの水平距離が 450 〜 3150 の 7 種類、指示物の方向が前、右斜め前、右、右斜め後乃、後 ろの 5 種類で、被験者は大学生の男性 9 名（平均身長：1679）、女性

表 1. 臥位での実験と立位での実験の概要

\begin{tabular}{|c|c|c|}
\hline & 臥位での実験 & 立位での実験 \\
\hline 実験場 & 体资館 & 体育館 \\
\hline 指示物 & 電球 & ビーールボール \\
\hline 指示物までの水平距離 & $0,450,900,1350,1800,2250$ & $\begin{array}{c}450,900,1350,1800,2250, \\
2700,3150\end{array}$ \\
\hline 指示物までの高さ & $\begin{array}{c}300,600,900,1200,1500 \\
1800,2100,2400,2700\end{array}$ & $\begin{array}{c}0,300,900,1500,1800,2100 \\
2400,2700,3000,3300,3900 \\
4500,5100,5700,6200\end{array}$ \\
\hline 指示物の方向 & 上、斜め上、横、斜め下、下 & $\begin{array}{c}\text { 前、右斜め前、右、右斜め後乃、 } \\
\text { 後ろ }\end{array}$ \\
\hline 贒問項目 & ○○は何だろう、○○は電球です & ○○は何だろう、○○はボールだ \\
\hline 被験者数 & 12名（M;6 F;6） & 23名（M;9 F;14） \\
\hline
\end{tabular}

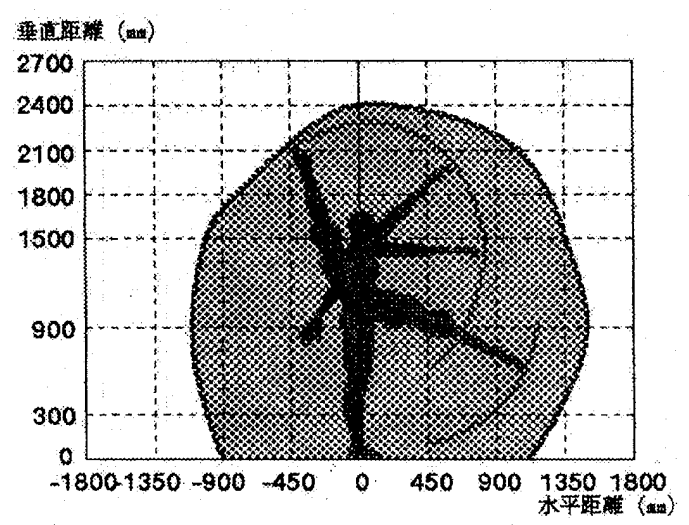

図11. 立位での「コレ」領域の大きさと動作域との関係対 
14名（平均身長：1591）の合計23名（平均身長：1635）であった。ま た、実験の手法・教示は本研究と同様であった。

実験の結果の中から、「コレ」領域に関するものについて抜粋した (「コレ」領域の形状については図 12〜14を参照)。「コレ」領域は、 前方向にもっとも広がり、高さが 2400 程度の卵型であり、本研究と 同様に、「ソレ」と「アレ」の領域の境界については、「コレ」と「ソ レ」の領域の境界よりも曖昧であった。また、「コレ」領域は、手を 伸ばせば届くような動作域に関連した身体的な領域であった(図11)。 4.2.2 臥位での「コレ」領域と立位での「コレ」領域との比較

ここでは、卧位での「コレ」領域と立位の「コレ」領域を比較し、 姿勢の違いが指示代名詞領域に与える影響について検証し、臥位の特 異性を検証した。臥位と立位での「コレ」領域を重ね合わせたものを 図 $12 \sim 14$ に示す註 ${ }^{14)}$ 。

卧での「コレ」領域は、ただ単に立位での「コレ」領域を 90 度 横にしただけのものではなく、立位での「コレ」領域よりも小さく、 形状も異なるものであった。水平方向の広がりでは、卧位では 800 付 近であったのに対し、立位では1400付近であった（図13）。垂直（高 さ）方向の広がりでは、臥位では 1100 付近であったのに対し、立位 では1500付近であった（図 14）。特に、立位での「コレ」領域は、身 体を完全に覆い隠す形状であったが、臥位での「コレ」領域では、足 下方向は膝あたりまでしかなく、身体の上半身を覆う程度の大きさで あったことが大きな差として挙げられる。

また、立位での「コレ」領域の大きさは、立位での動作域との関わ りが強く（図 11）、臥位の「コレ」領域の大きさが持つ意味と同様の 結果である (4.1参照)。つまり、「コレ」領域の大きさが持つ意味は、 姿勢に関わらず、同様であるが、「コレ」領域の大きさや形状は、そ の姿勢独自のものとなるといえ、卧位は立位に比べて、身体的な自由 度が低いことから、「コレ」領域の大きさは小さくなるといえる。

以上のように、臥位の「コレ」領域は、立位の場合とは異なり、臥 位特有の大きさを形成するといえる。

\section{5.まとめ}

以下に、指示代名詞の使い分けの分析によって明らかになった卧位 での指示代名詞領域の形状についてまとめる。

1. 臥位での「コレ」領域は、身体の頭から膝あたりまでを包み込み、 視点から 1000 付近を頂点とした卵型であり、その大きさは、動作 域との関連性が高い。

2. 臥位での「ソレ」領域は、領域の境界が曖昧であるが、「コレ」領 域を覆うような卵型を㔙成する。

3. 臥位での指示代名詞領域は、立位での指示代名詞領域とは異な り、臥位特有の領域を形成する。つまり、頭部を含めた身体の自 由度 (動作域) や視線の方向（見えやすさ）といった臥位の姿勢 的特徵に基づいた認知領域を形成している。

以上の結果から、指示代名詞領域といった観点からの臥位が持つ心 理的領域の形状が明らかになったと考える。今後は、より実際の生活 場面を意識した状況での実験が必要であると考える。

\section{謝辞}

本研究は、立米型住宅研究会 (代表者: 高橋鷹志・元 新潟大学教授) の一連の研究としておこなわれた。また、本実験は、木戸將人氏、渋

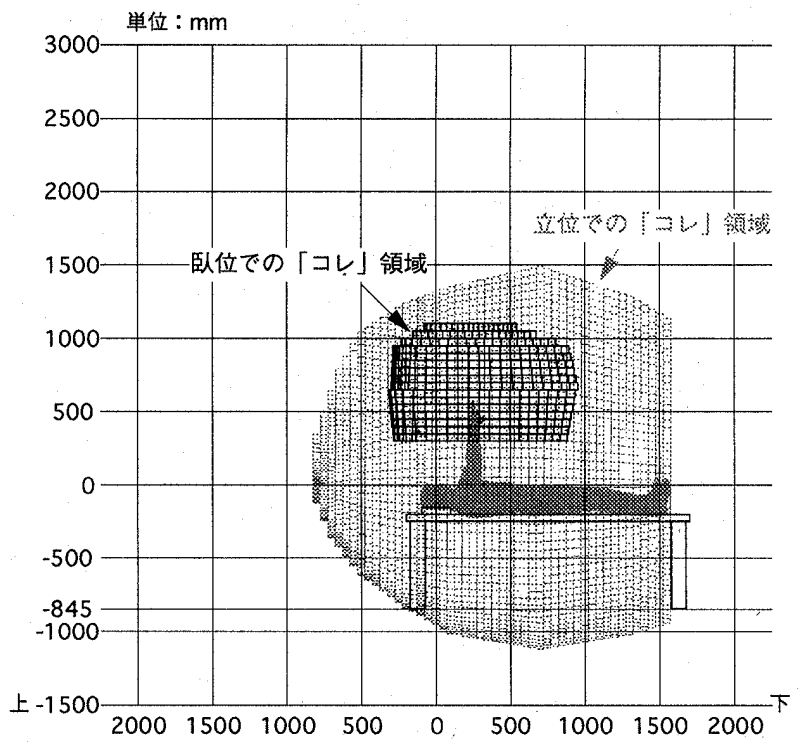

図 12. 臥位での「コレ」領域と立位での「コレ」領域との比較 (上下方向)

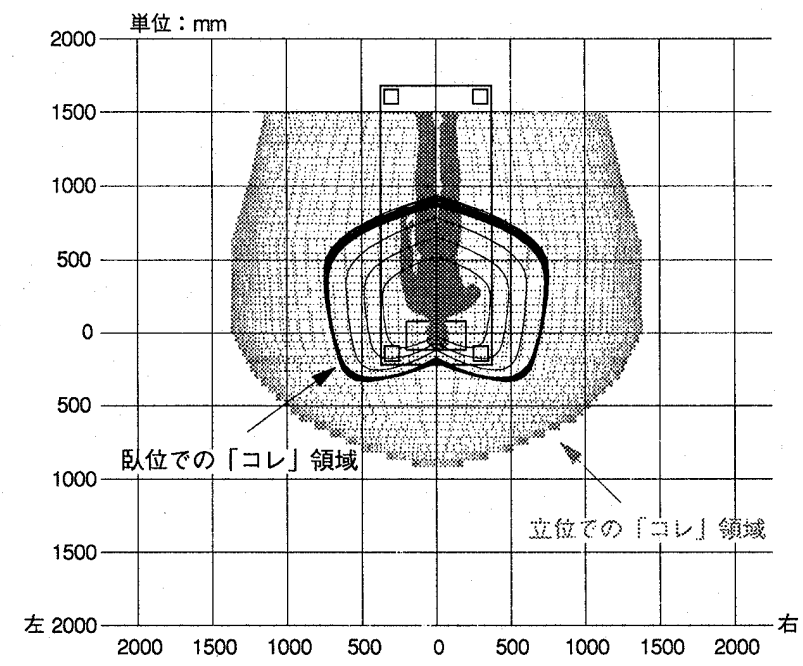

図 13. 臥位での「コレ」領域と立位での「コレ」領域との比較 (水平方向)

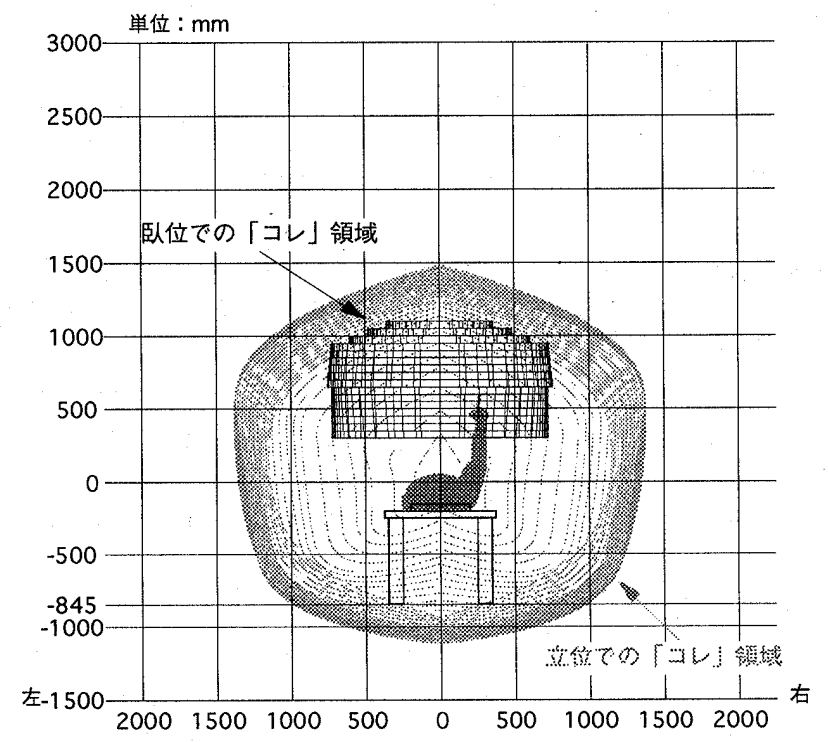

図 14. 臥位での「コレ」領域と立位での「コレ」領域との比較 (左右方向) 
江元保氏（当時：千葉工業大学西出研究室）の修士論文・卒業論文を 通じた共同研究である。

注

注 1 ）広辞苑第 5 版文1)によると、指示代名詞とは「事物・場所・方角などを 指し示すのに用いる代名詞」であると解説されている。

注 2 ）筆者らは、指示代名詞領域の一連の研究の中で、座位の場合についても 同様に検証しているが文ら、本研究では、卧位の場合のみを扱うこととした。

注 3 ) Personal Space とは「侵入者が入れないように、その人の身体をとり囲む 見えない境界をもった領域」を意味し、「もち運びのできるテリトリー」とい われている文6。

注 4 ) 実験場は、千葉工業大学・津田沼キャンパスにあったIDドーム（体育館） を利用し、実験期間は 1993 年 9 月 $28 、 29$ 日の 2 日間である。実験場の照度 は200〜3001xであった。

注 5 ) 被験者の人数は、既往の研究をみると、石川守 (1992) 文3) は20名（男 性 8 名、女性 12名)、橋本都子 (1996）文4) は23名（男性9名、女性 14名）、 大野隆造ら（1999）文11) は14名（男性5名、女性9名）、内田茂（1979）文12) は8～16名と様々であった。以上のことと実験条件（指示物のポイント数、 実験場など)を踏まえた上で、本実験では被験者の人数を 12 名とした。また、 本研究では、橋本都子 (1996) 文4) の立位での指示代名詞領域の結果を中心 に、姿勢の違いが指示代名詞領域に与える影響について検証する（姿勢を実 験の変数とする)ことを考虑したことも理由の一つである。さらに、被験者 の人数が少数ではあるが、回答のばらつきを判断する基準として、検定をお こなった (注 7 参照)。

注 6 ）教示文を以下の通りである。

「これから実験を始めます。実験室にはベッドと指示物である電球がありま す。実験室の所定の場所に寝てください。その際、目の位置が基準線に重な るように頭の位置を調節してください。あなたは、自分自身が疑問をもって、 明かりのついた電球を指さし、「○○は何だろう」・「○○は電球です」と言う とき○○のところに指示代名詞コレ、ソレ、アレのいずれを用いるかを答え、 用紙に記入してください。答える際は話し相手を想定せずにあくまでも自問 自答であることを考慮してください。」

併せて、被験者に教示をする際には、ベッド上に横になったときには、身 体は動かさず、頭だけ视から離れない程度動かしても良いことと、電球が見 えない場合は「見えない」と記入することを説明した。教示が終わった後に は、実験に関して疑問点や不明な点があるか否かを被験者に尋ねたが、質問 はなかった。また、実験の中で用いた指示代名詞については、「コレ・ソレ。 アレ」とカタカナで示すこととした。

注 7 ）被験者が選択した「コレ・ソレ・アレ」の回答数を各ポイントごとに集 計し、帰無仮説 Ho「被験者の回答の分布には偏りがない」のもと、 $\chi 2$ 検定 と多重比較をおこなった。 $\chi 2$ 検定と多重比較の方法については、参考文献 13）を参照した。

注 8 ) グレーゾーンの表し方は、有意差がみられなかったポイントを中心に、上 下左右のポイントまでの半分 (ポイントを中心に上下 150 ·左右 225 のグリッ ド）をグレーゾーンとして維で示した。

注 9）実験をおこなったのが、被験者の右側部分だけであったため、図 $5 \cdot 7 \cdot$ 8 については、右側の結果を左側に反転した状態を仮定して作成した。它の ため、図上では、左側の印を点線で薄く示した。ただし、石川守 (1992) 文3) の結果などからわかるように、指示代名詞領域の形状は左右対称であるとは いえない(図1参照)。

注 10）境界線を引いた基準については、「コレ」と「ソレ」の領域の境界部分 を、「コレ」と回答した被験者の割合が半数以下の地点とし、各指示物の高さ ごとに「コレ」と示された 5 個のポイント（上、斜め上、横、斜め下、下）の 近似曲線を引き、「コレ」領域を示した。さらに、各指示物の高さ間は、それ ぞれの高さの領域の差を 50 ピッチごとに平均分割して領域の境界線を引い た。また、注 9）にあるように、実験では右側部分だけであったが、右側部
分を左側に反転させて「コレ」領域を示した。さらに、立位での「コレ」領 域と比較する（「4.2 臥位での「コレ」領域と立位での「コレ」領域との比

較」参照）ために、領域の濃淡は左右同じで示した。

注 11）本実験では、指示物の高さが 300 以下については、指示物が見えにくい ことと実験方法・実験装置の限界から実験を抢こなっていないが、既往の研 究文い3) から考えても、300以下にも領域は広がっており、身体全体を取り 囲むような球状であると推測できる。

注 12）水平方向の広がりに比べ、垂直方向の広がりの方が広いのは、上部から 人が近づく可能性が低いことや視線が送りやすいこと、上体をおこすと届き そうなことなどによる影響と思わ机る。この点に関しては、今後の検証課題 とする。

注 13）根木睦二 (1984) 文16) の研究の中で、本研究と関連する部分を抜粋し、以 下に記す。実験は、臥位でのパーソナルスペースを検証するものであり、実 験空間内 (製図室) でベッド上に寝た被験者間の距離を変数とし、各設定ご とにその距離を評洒尺度（1，静かに休んでいるとしたら、2．ひとりで本 を読むとしたら、3．隣の人と話をするとしたら）を使って居心地を評定し た(被験者14〜21名)。その結果、評定值の変化と被験者間の距離によって、 以下の 5 つの距離帯に分類できることを明らかにした。1) 身体域：0～500、 2) 準身体域: $500 １ 000 、 3 ）$ 排他域: $1000 １ 500 、 4 ）$ 交流域：：1500 $\sim 2100 、 5$ ) 認撞域: $2100 \sim$ (単位: $\mathrm{mm}$ )。

注 14）臥位と立位を比較するために、立位での「コレ」領域を 90 度回転させ、 人の位置を臥位の場合に合わせて表示した。

\section{参考文献}

1）新村出編：広辞苑第 5 版、岩波新書、1998

2 ) 今井四郎: 指示代名詞の指示機能について、北海道大学文学部人文科学論 集 15 号、1978

3) 石川守：日本語指示詞「これ」「それ」「あれ」のダイクシス的用法の関す る調查、拓殖大学語学研究所 語学研究 第 68 号、pp.1-27、1992

4 ) 橋本都子: 人間の心理・認知に基づく空間規模に関する研究、日本女子大 学博士学位論文、1996

5 ) 西出和彦、橋本雅好ほか：座位における個人空間の領域分節、日本建築学 会学術講演梗概集（E-1）、pp.711-712、1997

6) Sommer, R. 著、䅖山貞登訳：人間の空間一デザインの行動的研究一、鹿島 出版会、1972

7) Hall, E.T. 著、日高敏隆ほか訳：かくれた次元、みすず書房、1970

8) 田中政子：Personal spaceの異方的構造について、教育心理学研究 21.4、 pp.223-232、1973

9）渋谷昌三：人と人との快適距離 パーソナル・スペースとは何か、日本放 送出版協会、pp.20-23、1990

10）西出和彦: 人間集合による空間形成に関する研究、東京大学博士学位論文、 1991

11）大野隆造、松田好晴：公共空間における他者の占有領域の知覚に関する研 究、日本建築学会計画系論文集 第 519号、pp.93-99、1999.5

12）内田茂：閉空間に対する感覚量に関する実験的研究 (1)、日本建築学会 論文報告集 第282 号、pp.113-122、1979.8

13）森敏昭、吉田寿夫：心理学のためのデータ解析テクニカルブック、北大路 書房、pp.57-68、1990

14）小原二郎編：デザイナーのための人体・動作寸法図集、彰国社、p.89、1984

15）国立国語研究所編：日本語の指示詞、大藏省印刷局、1981

16）根木睦二:臥位におけるパーソナルスペース一病室のベッド配置に関する 心理的考察一、東京大学修士論文、1984

17）木戸將人、西出和彦ほか：臥位に㧍ける個人空間の領域分節、日本建築学 会学術講演梗概集（E)、pp.1009-1010、1994

（2001年10月 9 日原稿受理，2002年 3 月25日採用決定） 